\title{
Review of the Domestic Crowdfunding Industry Development
}

\author{
Defeng Yang, Xueli Zhang \\ Jinan University, Guangzhou, China \\ Email: 467020485@qq.com
}

Received 3 December 2015; accepted 14 February 2016; published 17 February 2016

Copyright (C) 2016 by authors and Scientific Research Publishing Inc.

This work is licensed under the Creative Commons Attribution International License (CC BY). http://creativecommons.org/licenses/by/4.0/

c) (i) Open Access

\begin{abstract}
2014 was called "the first year of the crowdfunding in China". The State Council executive meeting on Nov. 19, 2014 put forward that we must establish a rapid refinance mechanism for capital markets, trying to launch equity crowdfunding. In December, the Securities Association of China solicited opinions on management measures of the private equity crowdfunding, which boosted the crowdfunding into the "fast track". A lot of crowdfunding platforms appeared including the three giants (Jingdong, Taobao, Suning). The three giants occupied most of the market share. Other platforms constantly followed. Domestic crowdfunding industry has entered the flourishing mode. This paper analyzes the domestic developments of various crowdfunding platforms.
\end{abstract}

\section{Keywords}

\section{Crowdfunding, Platform, Financing}

\section{Introduction}

Almost all the companies face the financing problem, especially some small businesses. Getting a bank loan needs enough assets as mortgage. Seeking venture capital firm for help needs a perfect enough project. But some small companies or just some guys really have good ideas. They have no capacity to receive financial support from the traditional institutions. Then we think of the Internet. The greatest benefit we can get from the Internet is that we can get to people from anywhere. Distance is not a problem anymore. People from distance can reach an agreement if they have the same interest. A person has a creative idea, if he can make out certain product, he will attract many consumers. But he doesn't have enough money to produce them. At the same time, there are some other guys having some spare cash. Each of them does not have too much money. They want to do some investment, but they don't know what to do and each of them can't afford a project as well. OK, these guys can make a connection on the Internet. The one who has an idea can post his project on the Internet, leaving his 
contact details. The other guys can scan some information on the Internet and connect the initiator if they have an interest in the initiator's project. This financing way is crowdfunding. Crowfunding does not need capital demander to provide mortgage. All he has to do is to put the project on the Internet and update it.

The definitions of crowdfunding raised by scholars are not much different. Table 1 shows the definitions of crowdfunding raised by scholars.

Crowdfunding involves three participations: initiator, supporter and approver. Initiator: project provider and capital demander. Supporter: interested in the project and have spare money to support it. Approver: connect the initiator and supporter, provide a platform, check the project and guarantee the interest of the supporters. First, the initiator submits a project profile including a title, description of planned use of funds, funding goal, video, campaign duration, and reward descriptions etc. Then the approver checks the material. If the project is approved, the platform presents their work in a preformatted page where visitors can choose to donate. Creators use a variety of means to reach potential supporters, including the crowdfunding platform itself, email, and online social media, as well as offline communication technologies and in-person requests. Once the campaign is over, they follow through with their proposed project. This stage of work involves producing and delivering the promised rewards. Rewards range from having one's name acknowledged in the movie credits, to getting the new crowdfunded product, to receiving a simple "thank you" email from the creators. Figure 1 shows the working process of the crowdfunding.

\section{Table 1. The definitions of crowdfunding raised by scholars.}

\begin{tabular}{|c|c|}
\hline Schwienbacher (2010) & $\begin{array}{l}\text { Crowdfunding is a project or innovation that financing from a group of individuals instead of raising funds } \\
\text { from professional financial institutions. It is still in its infancy [1]. }\end{array}$ \\
\hline Belleflamme (2011) & $\begin{array}{l}\text { Crowdfunding is a public tender. New companies raise funds from the public through the Internet to achieve a } \\
\text { special goal. The companies can return the public with many ways, such as products, stock or nothing. } \\
\text { They just do some donation [2]. }\end{array}$ \\
\hline Bechter (2011) & $\begin{array}{l}\text { The procedure of financing is translating the information to the public through social networks. } \\
\text { The providers can participate in the project [3]. }\end{array}$ \\
\hline Ghose (2012) & $\begin{array}{l}\text { Crowdfunding is a unique combination of collective evaluation and public funding. The public choose a project } \\
\text { they want to support by investing it. At the same time they will give some advices to the initiator [4]. }\end{array}$ \\
\hline Julie (2012) & Crowdfunding emphasizes the intellectual property as well as the public capital [5]. \\
\hline Molick (2013) & $\begin{array}{l}\text { Crowdfunding is the individuals or organizations get a small amount of money as the start of project funding } \\
\text { from a relatively large amount of people [6]. }\end{array}$ \\
\hline
\end{tabular}

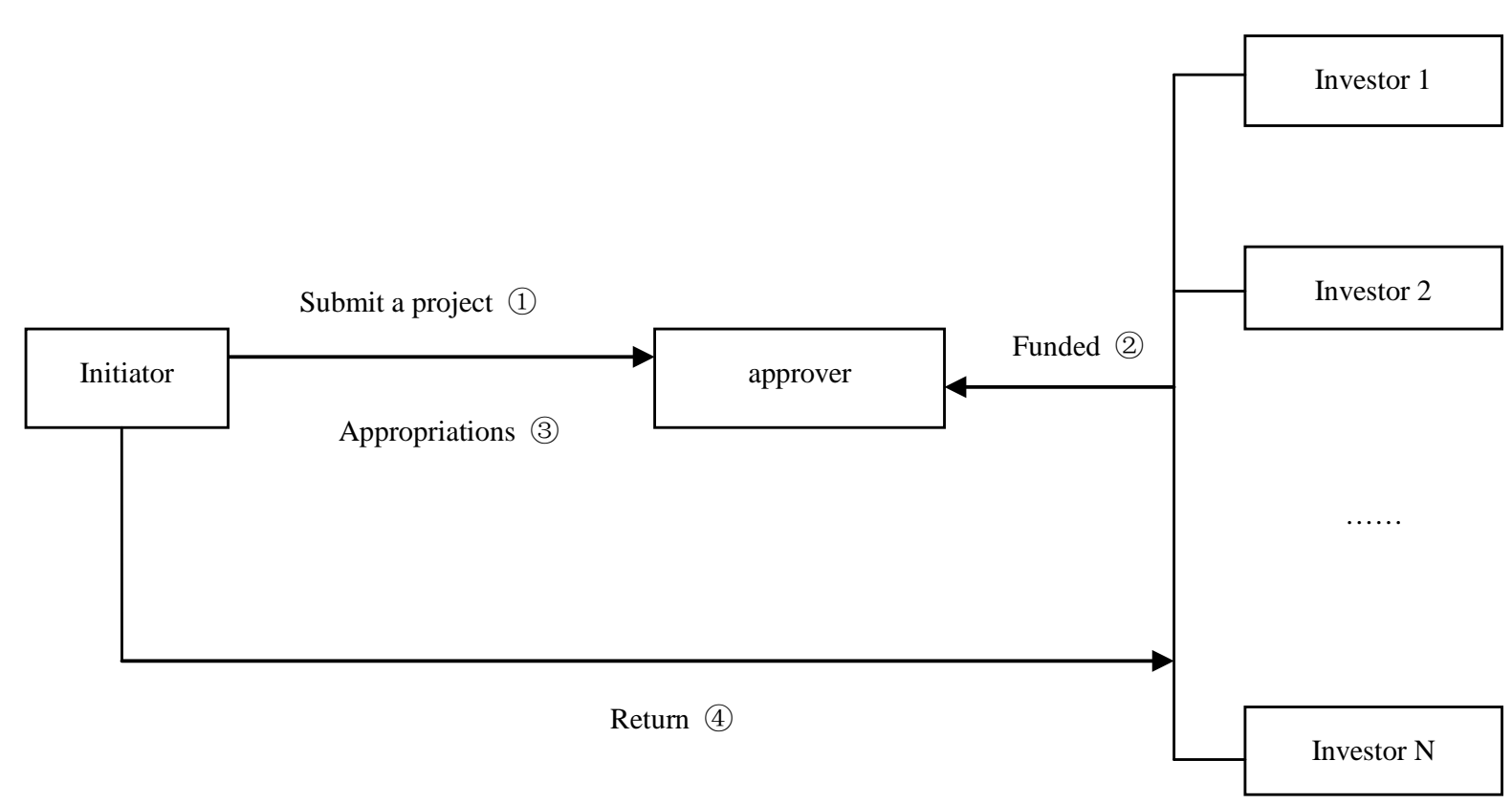

Figure 1. Working process of the crowdfunding. 


\section{Big Events of Crowdfunding at Home and Abroad}

In recent years, crowdfunding developed rapidly. Table 2 and Table 3 lists the big events abroad and domestic respectively.

\section{The Current Situation of Domestic Crowdfunding Industry}

In China, the crowdfunding has experienced a rapid development period in 2014. According to iResearch statistics, the total size of crowdfunding market has reached 440 million RMB in the year of 2014. So far, there are four kinds of crowdfunding. The first one is reward crowdfunding. Which means that if you give me one dollar, I will give you the corresponding commodity within the stipulated time. The second one is the donation crowdfunding. They support the project for nothing, just because they like it. The third one is the equity crowdfunding. It means that if you give me one dollar, I will promise you the corresponding shares. The last one is bond crowdfunding. That is if you give me one dollar, I'll give you the corresponding interests. These four modes are not entirely raising money. It can help to get funding to promote projects. It can also help the enterprise to get a bunch of advocates.

Reward crowdfunding accounts for the major crowdfunding market. Taobao crowdfunding, Jingdong crowdfunding and Suning crowdfunding represent the reward crowdfunding. Base on the data from data.01caijing.com, we got the top ten crowdfunding platforms. The ranking is based on the total money raised up to October 2015. Table 4 shows the money raised by the top ten platforms up to October 2015 [7].

Table 2. Big events of crowdfunding abroad.

Abroad:

Mar. 2005 The world's first P2P microcredit network platform named ZOPA (UK) was established. This is the prototype of borrowing crowdfunding.

Aug. 2006 Michael Sullivan created Fundalog (United States) financing platform on the Internet. And explain the core idea of the platform in his micro-Bo with the word of crowdfunding. It's the first time to use crowdfunding as a proper noun.

Aug. 2006 The first music-themed crowdfunding website named Sellaband (Netherlands) was found. It is the world's first successful crowdfunding website. It is also the largest cultural crowdfunding platform currently.

Jan. 2008 IndieGoGo (USA) started to work. It is one of the world's most successful crowdfunding websites. It is also the world's largest international crowdfunding platform nowadays.

Apr. 2009 Kickstarter (USA) started to work. It is known as the leader of crowdfunding websites. It's also the largest crowdfunding platform in the world.

Sept. 2009 FundRazr (Canada) is started. It is the first crowdfunding website to use the Facebook to raise money from public directly.

Apr. 2011 SEC Chairman Mary Schapiro discus the future of the equity crowdfunding 's regulation reform in the WSJ.

Apr. 2011 It's the first time to place some questions about crowdfunding on the agenda.

Apr. 2012 President Obama signed the JOBS Act. Article III provides legal support of crowdfunding 's operation and regulatory.

May. 2013 Smart watch manufacturers Pebble financing \$1,500 in Kickstarer successfully, which is the highest record.

2013 The European Commission officially announced that they will support the development of crowdfunding in the EU.

\section{Table 3. Big events of crowdfunding domestic.}

Domestic:

Jul. 2011 Demohour went online. Since then, Dreamore, Tmeng etc. has come to work in succession one after another.

Nov. 2013 During the double eleven Taobao launched their own crowdfunding platform named Amoy Xingyuan. Which mainly uses the star effect and the large number of Taobao users to drive the development of economic.

Apr. 2014 Baidu began to do the crowdfunding experiment.

Jul. 2014 Jingdong began to do the crowdfunding experiment.

Zhongchoukongjian launched the easy crowdfunding, which mainly consists of two concepts. One is social crowdfunding,

Aug. 2014 which means that the initiator can promote his project in his social circle (micro-channel, microblogging, QQ, etc). Another one is little crowdfunding, which means the programs needed less money.

Oct. 2014 Nine crowdfunding platforms combined and signed the crowdfunding treaty.

Jun. 2015 The State Council issued “Some opinions about promoting The public entrepreneurship”. In which they express the strong supportive attitude toward the equity crowdfunding. 
Table 4. The money raised by the top ten platforms up to October 2015.

\begin{tabular}{cc}
\hline Jingdong Crowdfunding & 10343.7 Million RMB \\
Taobao Crowdfunding & 6248.8 Million RMB \\
Suning Crowdfunding & 187.68 Million RMB \\
Zhongchou.com & 135.58 Million RMB \\
demohour.com & 33.83 Million RMB \\
dreamore.com & 29.43 Million RMB \\
qingju.com & 27.55 Million RMB \\
themakers.cn & 20.15 Million RMB \\
kaistart.com & 10.93 Million RMB \\
modian.com & 8.69 Million RMB \\
\hline
\end{tabular}

Taobao crowdfunding is a typical reward crowdfunding. Most of its projects belong to the pre-sale category. Its projects can be classified into science and technology, home, design, entertainment, agriculture and public six categories. Taobao's data shows that it has calculated 99 million RMB up to Nov. 2015. The number of participants has over 5.251 million. Sponsors may initiate pre-sale of the innovative production on the platform. They also commit to provide different forms of return to supporters. Sponsors and supporters are Taobao sellers and buyers. The cash involved is guaranteed by the third party. Only sponsor paid for the supporters in accordance with the convention and confirmed by the receipts, the sponsors could get the total funds. In addition, Taobao will introduce the commercial insurance to guarantee the supporters' interest. The projects' successful rate are over $95 \%$. The high successful rate is due to the large number of the users. Huge crowd make the platform a best testing ground for the projects. Whether the project can success would be a signal of the market. If the project is ok, then the sponsor can open a shop on the platform, which can be a guarantee for the sustainable development. There are so many kinds of product on the Taobao. So they can identify which kind of project will be welcomed. The sponsors trust it and the supporters like it. It's a good virtuous cycle.

Jingdong crowdfunding is the most mature one at present. Jingdong was found later than Taobao. But now it takes the most share of the market. From the website we can see that their projects can be classified into four types, that is product, public, equity and debts. According to the statistic, Jingdong has calculated 1171 million RMB. Addition to the product, Jingdong does well in the equity crowdfunding. The mode is that there is a leader does the investment first, then others follow him. This model can help Start-up Enterprises to solve the financing problem. And every investor needn't take much risk. Jingdong shows a clear layout and invest much resources on the development of crowdfunding. From the product crowdfunding to equity crowdfunding, and even some supporting services, Jingdong sets up a complete ecosystem.

Suning becomes one of the troika in crowdfunding this year. Similar to Taobao and Jingdong, Suning's projects can be classified into science and technology, design, entertainment, culture, agriculture and public six categories. Addition to presale, Suning wants do something different. We can see a project labeled "making money while watching football”. This is a experimental project held by Suning, Wanxiang Trusts and Jindu Solicitors named "PPTV Champions League Football Toocle". As long as a user buy a quota of the project, he can become the PPTV member. At the same time, he can earn the value-added benefits. It is learned that there are many crowdfunding platform. But much of their projects are group purchase or presale. That can not give crowdfunding much energy. Crowdfunding is a combination of finance and Internet. Suning just take the point. If the project can success, Suning provides a new prospection for crowdfunding.

Welfare crowdfunding is an important part. Even it takes a less proportion of the market, it plays an important role in promoting social harmony. Tencent Donation is the most influential platform. It was found in 2014. They committed to philanthropy, care for the youth development and promote the corporate and civic responsibilities. Up to now, Tencent has donated 400 million. And it has made 1148 projects. Projects mainly cover illness assistance, student education, poverty relief, environmental/animal protection etc.

Equity crowdfunding refers to the company lets out a certain percentage of shares, the investors can buy it 
through the crowdfunding platform. Equity crowdfunding is a high risk and high return project. So the platform must be more cautious about the projects. Zhongbangtou is a typical one. Zhongbangtou was found in 2014. It takes the mode of leader and followers. That is there is a leader does the investment first, then others follow him. There are many kinds of projects. Users can invest the growing enterprise as well as the private equity fund issued by venture capital institutions. Zhongbangtou has calculated more than 500 million RMB. The basic requirements for on-line projects are as follow: The company must have been established more than 2 years. The revenue of last year must be over 10 million RMB, and the net profit of last year must be over 1 million RMB. The company that has signed with brokerages has a top-priority. The leader company of the high-growth industry has a top-priority. If the there are professional institutional investors in the shareholders, the company has a top-priority. The company which will list or has already listed on the New OTC Market has a top-priority. The above conditions improve the quality of the on-line projects. The platform also has a high requirements for leader investor. The leader must have some successful investment experience, have a great influence in the industry.

\section{Problems and Suggestions}

As a whole, the crowdfunding industry has an explosive development. But there are still many problems. For the platform, most of the platforms do not find their own profit model. They may face many problems such as lacking of projects, lacking of users, lacking of profit etc. in the near future. As for the projects, many of them have lower quality. And the platform also has the responsibility. They are not professional enough to check the projects. As for the supporter/investors, Chinese people lack of the awareness of risk, especially with equity crowdfunding. When the project is fail, most of the supporters can't accept the reality as they expected too much before. At the same time, the laws about crowdfunding are not perfect. It's easily lead to legal disputes.

Here we give some advices to the platform. To the supporters: they must give some risk education to the supporters. Remind them the risk about projects. To the projects: improve the professionalism, reduce the risk. To themselves: At first, each of the platforms must has a unique model, forming its own characteristics. Then, put the platform into mobile phone. With APP's explosive growth, it is so convenient to do everything with mobile phone. Every platform must take the opportunity. At last, strongly recommends that the Government should introduce policies to support the development of crowdfunding.

\section{Conclusion}

Crowdfunding is a new thing. Although still in its infancy, it represents a new trend of future development. Its unique characteristics can provide a new way to financing for small business. Our country has a large number of Internet users. If we can make a full use of the crowdfunding, many companies can benefit from that. We just make an overview of the crowdfunding. There are so many things worth studying.

\section{References}

[1] Schwienbacher, A. and Larralde, B. (2010) Crowdfunding of Small Entrepreneurial Ventures. SSRN Electronic Journal, 10, 1-23. http://dx.doi.org/10.2139/ssrn.1699183

[2] Belleflamme, P., Lambert, T. and Schwienbacher, A. (2011) Crowdfunding: Tapping the Right Crowd. International Conference of the French Finance Association, 5, 11-13.

[3] Bechter, C., Jentzsch, S. and Frey, M. (2011) From Wisdom of the Crowd to Crowdfunding. Journal of Communication and Computer, 8, 951-957.

[4] Burtch, G., Ghose, A. and Wattal, S. (2012) An Empirical Examination of the Antecedents and Consequences of Investment Patterns in Crowd-Funded Markets. SSRN Electronic Journal, 7, 1-48.

[5] Hui, J.L., Gerber, E. and Greenberg, M. (2012) The Demands of Crowdfunding Work. Northwestern University, Segal Design Institute.

[6] Molick, A.N.D. (2013) The Dynamics of Crowdfunding: Determinants of Success and Failure. Journal of Business Venturing, 6, 1-18.

[7] Crowdfunding (2014) Wikipedia [EB/OL]. http://en.wikipedia.org/wiki/Crowdfunding 